\title{
セスジアカムネグモの生態
}

\author{
大熊千代子

\section{Some observations on the habits of Oedothorax insecticeps Boesenberg et Strand (Araneae)}

By Chiyoko OKuma

1. 序言：セスジアカムネグモ Oedothorax insecticeps BOESENBERG et STRAND は 1906年，佐賀の標本に基づき，新種として記録された．以来，北海道（斉藤，1939；八 木沼，1957），青森県（八木沼，1958），長野県（干国，1941），大阪府（八木沼，1938. 小村，1952）等で記録されたが，その生態は殆んど明らかでなかった，しかし，近年に 到つて，水田のくもの調査が進もに従い，各地から発見され，水田に於けるその棲息密 度のたかさによつて，他の数種のくもと共に特に注目されるようになつた．筆者は1955 -1956年，元佐置県立農事試験場の於保信彦技師の教劣によつて，はしめて水田に於け るセスジアカムネグモの状態を知り，その生態調査が極めて興味あるものでるる事を知

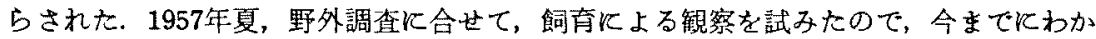
つたことを、一応まとめて報告する.

2. 棲息場所及ひ習性：棲息場所について，今迄に，セスジアカムネグモては，落葉 の下（小村, 1952), 水田(小林，1957，1958，外）等が記録されている。同属では, アンネンムネアカグモ (O. anneni) 及びスソクロムネアカグモ (O. melanopygus) が, 石や石垣の上で採集されて括り（安念，1941），ヨツボシアカムネグモ(O. quadrimaculatus）及びアトグロムネアカグモ (O. femineus) が山村地帯の樹間に棲息することが 報じられてい（干国，1941）、外国火於ける同属のものでは，私の知つている䇛囲で は，“湿つた草むら”とされたのが 2 種（O. gibbosus，O. agrestis）“草むら，下生兄” が 3 種 (O. fuscus, O. retusus, O. apicatus) ある. (Locket and Millidge, 1953). 福岡市近郊に於いてみられるセスジアカムネグモの主な楼息場所は次の通りである. 越冬期 (11月-3月) 平地の落集, 土塊, 石の下.

活動期 (4月-10月) 水田, 湿つた畑や草むら.

便宜上活動期とした4月から10月にかけて，上記の場所で，このく向の各世代をみる ことが出来，その大部分は，地表近くに不規則網を造つて棲息する．即ち，キャベッの ような広葉の植物に棲息するときは，地表を覆うょうとしている下葉の裹に系を数本張 りめぐらして，直立した植物，例えば稲や麦，多くの雑草の根元に棲息するときは，不 規則な系をせいぜ、 $25 \mathrm{~cm}^{2}$ 位飞張りめぐらしてその下側を主な活動の場とする.しか

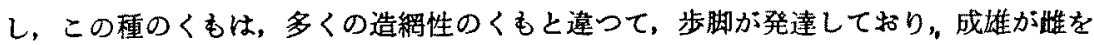

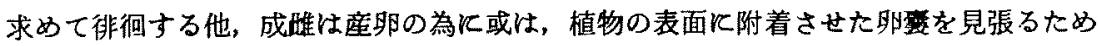


ス、網をはなれて俳泪性を帯びる。

このくもの食性飞関しては，水田に於いて，ッマグロヨコバイの幼虫及び成虫, ウン カ、トビムシ，フタテンヨコバイ，アブラムシ，ユスリカが捕食され，共食もあること がすて飞報告されて括り（小林，1958），その捕虫の方法は，上記のよ弓に俳䧃性を帯

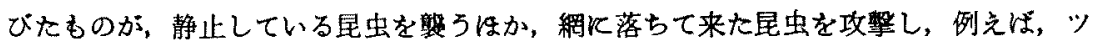
マグロヨコバイのようK，くもの体の何倍もあるようなるのる，巧み飞系をからませて 翅や脚の自由をらばい，簡単炇伥すといつた二つの方法があるようである。

3. くもの捕食量：捕食量の管㼛内試験を試みた. $1 \times 6 \mathrm{~cm}$ の管㼛飞, 水を含ませた 淒紙片を入れ，かるく綿栓したものを容器とし，野外で探集した 10 頭の成批を 1 頭ず \分封して，食䬣昆虫には，ウンカ類を主として，ユスリカ，ヨコバイ類を混ぜて用い， 粭与虫数と，24時間江整した虫数を年日記録した（第一表）。この表から直ちに捕食虫

\begin{tabular}{|c|c|c|c|c|c|c|c|c|c|c|c|c|c|c|c|c|c|c|c|c|}
\hline & & \multicolumn{2}{|c|}{ A } & \multicolumn{2}{|c|}{ B } & \multicolumn{2}{|c|}{ c } & \multicolumn{2}{|c|}{ D } & \multicolumn{2}{|c|}{ E } & \multicolumn{2}{|c|}{$\mathbf{F}$} & \multicolumn{2}{|c|}{ G } & \multicolumn{2}{|c|}{$\mathbf{H}$} & I & \multicolumn{2}{|c|}{ J } \\
\hline \multirow[t]{10}{*}{6 月 } & 21日 & 10 & 10 & 9 & 9 & 8 & 5 & 6 & 5 & 4 & 3 & 5 & 5 & 7 & 7 & 5 & 5 & 66 & 9 & 9 \\
\hline & 22日 & 5 & 5 & 5 & 5 & 3 & 3 & 4 & 4 & & $* 4$ & $\mathbf{5}$ & 5 & 3 & 3 & 5 & 5 & 55 & 5 & 5 \\
\hline & 23日 & 5 & 5 & 9 & 5 & 7 & 5 & 8 & 5 & 7 & 5 & 7 & 7 & 5 & 4 & 4 & 4 & 66 & 6 & 5 \\
\hline & 24 日 & 4 & 4 & 6 & 4 & 6 & 5 & 4 & 4 & 7 & 4 & 7 & 5 & 4 & * 2 & 5 & 3 & $5 * 5$ & 5 & 0 \\
\hline & 25 日 & 11 & 10 & 7 & 5 & 8 & 3 & 5 & 5 & 6 & 6 & 4 & 4 & 6 & 4 & 7 & 4 & 73 & 5 & 1 \\
\hline & 26日 & 6 & 3 & 5 & 3 & 7 & 7 & 4 & 2 & 6 & 6 & 5 & 4 & 5 & 5 & & 5 & 40 & 4 & 2 \\
\hline & 27 日 & 7 & 4 & 4 & 4 & 7 & 6 & 8 & 8 & 6 & 5 & 4 & 1 & 6 & 5 & 5 & 5 & 65 & 5 & 2 \\
\hline & 28 日 & 5 & 5 & 5 & * 5 & 7 & 7 & 5 & $\mathbf{5}$ & 5 & 5 & 3 & * 3 & & * 4 & 5 & 5 & 55 & 5 & $\mathbf{5}$ \\
\hline & 29 日 & 7 & 7 & 5 & 5 & 7 & 6 & 7 & 6 & 9 & 8 & 6 & 6 & 9 & 5 & 5 & 5 & 55 & 5 & 3 \\
\hline & $30 \mathrm{~B}$ & & * 4 & 11 & 8 & 6 & 6 & & * 6 & 6 & 4 & 10 & 9 & 9 & 9 & 5 & 5 & $6 * 5$ & 3 & 0 \\
\hline 合 & at & & 57 & 66 & 53 & 66 & 53 & 57 & 50 & 62 & 50 & 56 & 49 & 55 & 48 & 50 & 45 & $\begin{array}{ll}55 & 45\end{array}$ & 52 & 31 \\
\hline \multicolumn{2}{|c|}{ 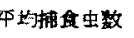 } & \multicolumn{2}{|r|}{5.7} & \multicolumn{2}{|c|}{5.3} & \multicolumn{2}{|c|}{5.3} & \multicolumn{2}{|c|}{5.0} & \multicolumn{2}{|c|}{5.0} & \multicolumn{2}{|c|}{4.9} & \multicolumn{2}{|c|}{4.8} & \multicolumn{2}{|c|}{4.5} & 4.5 & \multicolumn{2}{|c|}{3.1} \\
\hline
\end{tabular}

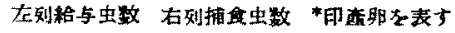

数を算出することは出来ない，全体の53\%は与えられただけの食䬣昆虫を完全に整して 抢り，多いあのでは 10 頭に及んでいる（A，6月21日）。このことから給与蜘を更に 增加した場合，捕食虫数も更に幾割か增加するものと思われ，この 試験は全く不充分たつたと云える.しかし，10日間の累計で，䊀 与虫数仅対する捕食率が $90 \%$ を越えていない事から，こ」では一 応 3 頭乃至 5，6頭位を捕食するものと考えたい.

4. 産卵及ひ経週：前項でも述べたうと，卵は棲息場所近くの 植物の表面に，うすい膜に包まれて，平たく産みつけられる。野外 で乱獲した27ケの卵塊で卯数を調べたこる（第二表），31 から 40 ケが最も多く，1 卯塊中の平均卵数は 36 から 37 ケ位であつた.

次飞産即回数を調へるために，野外で採集した崔雄を 1 組づょ，

\begin{tabular}{|c|c|}
\hline 卵 の 数 & 那坮数 \\
\hline 20 以下 & 3 \\
\hline $21-30$ & 3 \\
\hline $31-40$ & 14 \\
\hline $41-50$ & 3 \\
\hline $51-60$ & 4 \\
\hline 60 以上 & 0 \\
\hline 992 & 27 \\
\hline
\end{tabular}




\begin{tabular}{|c|c|c|c|}
\hline 深 & 集 日 & 6 月20日 & 6 月 20 日 \\
\hline 第 & 回造䎳 & 6 月 $30 \mathrm{~g}$ & 6 月 24 日 \\
\hline 第 & 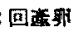 & 7 月9日 & 7 目1 \\
\hline 第 & 回遴例 & 7 月15日 & 7 月 8 日 \\
\hline 第 & 回造卵 & 7月19日 & 7月12日 \\
\hline 第 & 回造那 & 7月24日 & 7 月 18 日 \\
\hline 第 & 回青那 & 7 月31日 & 7 月 25 日 \\
\hline 第 & 回表卵 & 8 月 5 日 & 7月 30 日 \\
\hline 第 & 回部躭 & 8 月 12 日 & 8月 5 日 \\
\hline 第 & 回造嘞 & 8月18日 & 8月 9 日 \\
\hline 第 1 & 0回血䀧 & 8月24日 & 8 月 16 日 \\
\hline 第 1 & 1回趧卵 & 8 月29日 & 8月 26 日 \\
\hline 第 1 & 2回哇那 & 9 月 3 日 & \\
\hline 第1 & 3回造卵 & 9月11日 & \\
\hline 第1 & 4回速卯 & 9 月17日 & \\
\hline 死 & 亡 & 10月3日 & 8月28日 \\
\hline
\end{tabular}

\begin{tabular}{|c|c|c|c|c|c|}
\hline & A & $\mathbf{B}$ & c & $\mathbf{D}$ & E \\
\hline 造 & 6 月 24 日 & " & " & 6 月 26 日 & 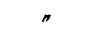 \\
\hline 出 & 7 月 2 日 & " & , & " & " \\
\hline 策 1 回脱皮 & 7 月 8 日 & 7 月 8 日 & 7 月 8 日 & 7 月 10 日 & 7 月13日 \\
\hline 第 2 回脱皮 & 7 月16日 & 7 月16日 & 7 月13日 & 7 月 18 日 & 7 月19日 \\
\hline 第 3 回脱皮 & 7 月 22 日 & 7 月19日 & 7 月20日 & 7 月 25 日 & 7 月 30 日 \\
\hline
\end{tabular}

湿気を保たせた管瓶内で，日に数頭当ての食䬣昆虫を与 えて飼育し，産卯状態を記録した. 試供材料としたくも は未だ産卵していないと思われるものを選んだが，確信 はもてない，それによると，座卵回数は非常に不揃いで おつたが，第三表に最む産卵回数の多かつたもの 2 例の 産卵状態を示す．産卵回数14回のものを例にとると，約 500卯強を産卵した事になる。

卵は，飼育観察を行つた 6 月から9月にかけては，例外なく5 日目に睤化し，6，7 日目に出盧した. 6 月24日及び 6 月26日に産子つけられた 2 はらの出盧後の経過を第四

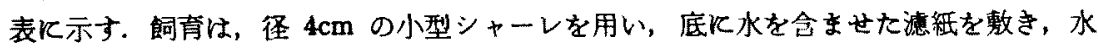
を充分に与え，食䬺には，出盧後約10日間（体長 $1 \mathrm{~mm}$ 足らず）は朝や脚を切つたュス リカを主として与え，第 1 回脱皮挠からはウンカ類を与えた. 性徽は，第三回脱皮後は じあて現れ，その後2，3日を経過して完全に成熟した.これらはすべて雄であつた.

これとは別飞，成穛ぐも飼育中の径 $8 \mathrm{~cm}$ のシャーレ内で，仔ぐあが 1 頭育ち，経過 は明らかでなかつたが，1ケ月後に産即をはじめた。これらの事を総合すると，䛇期は 5 日，幼期は約 1 ケ月，産卵期間は 2，3ケ月で, 野外飞抽いてすで観察されている ようК (小林, 1958 ; 外)，少なくとす食慨の豊富な4月から10月にかけては，幾世代 もが重なることがわかる.

この調查で明らかにされなかつた，越冬期の状態，繁殖期間，年間の消長，又は捕食 量や食餉について，本年度は更に計画的な調查を試みたいと思つている.

最後に，色々御教示頂いた於保信彦，小林尚両技師，御校閲を頂いた安松京三教授に 深謝の意を表する。

\section{文献}

安念 嘉一, 1941, Acta Arachnol., $6: 108-111$.

干国安之輔，1941，日本アルプス山系の蜘蛛 (長野)，81-83.

小林尚, 1957, 籼虫剂散布による水田昆虫相の変動関する特殊調查。1956年度 の成績 (德岛䀠崑業試験場)。

1958, 同. 1957年度の成樍.

齐藤 三郎, 1939, Saito Ho-on Kai Museum Res. Bull., $3: 55$.

植村 利夫, 1937, Acta Arachnol., $2: 150-153$.

八木沼健夫, 1957, Acta Arachnol., $14: 54$.

1958, 資源科学研究所篓報, 46-47:71.

Boesenberg, W. u. Strand, E., 1906, Abhandl. Senck. Naturf. Ges., $30: 163$.

Locket, G.H. \& Millidge, A.F., 1953, British Spiders (London), II : 238-243.

Savory, T.H., 1953, The Spiders \& Allied Orders. (London) : 116. 